\title{
Front Matter: Volume 6663
}

, "Front Matter: Volume 6663," Proc. SPIE 6663, Laser Beam Shaping VIII, 666301 (2 October 2007); doi: 10.1117/12.774218

SPIE Event: Photonic Devices + Applications, 2007, San Diego, California, United SPIE. States 


\section{PROCEEDINGS OF SPIE}

\section{Laser Beam Shaping VIII}

Fred M. Dickey

David L. Shealy

Editors

28-29 August 2007

San Diego, California, USA

Sponsored and Published by

SPIE 
The papers included in this volume were part of the technical conference cited on the cover and title page. Papers were selected and subject to review by the editors and conference program committee. Some conference presentations may not be available for publication. The papers published in these proceedings reflect the work and thoughts of the authors and are published herein as submitted. The publisher is not responsible for the validity of the information or for any outcomes resulting from reliance thereon.

Please use the following format to cite material from this book:

Author(s), "Title of Paper," in Laser Beam Shaping VIII, edited by Fred M. Dickey, David L. Shealy, Proceedings of SPIE Vol. 6663 (SPIE, Bellingham, WA, 2007) Article CID Number.

ISSN 0277-786X

ISBN 9780819468116

Published by

SPIE

P.O. Box 10, Bellingham, Washington 98227-0010 USA

Telephone +1 3606763290 (Pacific Time) · Fax +1 3606471445

SPIE.org

Copyright (C 2007, Society of Photo-Optical Instrumentation Engineers

Copying of material in this book for internal or personal use, or for the internal or personal use of specific clients, beyond the fair use provisions granted by the U.S. Copyright Law is authorized by SPIE subject to payment of copying fees. The Transactional Reporting Service base fee for this volume is $\$ 18.00$ per article (or portion thereof), which should be paid directly to the Copyright Clearance Center (CCC), 222 Rosewood Drive, Danvers, MA 01923. Payment may also be made electronically through CCC Online at copyright.com. Other copying for republication, resale, advertising or promotion, or any form of systematic or multiple reproduction of any material in this book is prohibited except with permission in writing from the publisher. The CCC fee code is $0277-786 \mathrm{X} / 07 / \$ 18.00$.

Printed in the United States of America.

Publication of record for individual papers is online in the SPIE Digital Library.

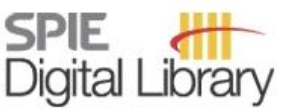

SPIEDigitallibrary.org

Paper Numbering: Proceedings of SPIE follow an e-First publication model, with papers published first online and then in print and on CD-ROM. Papers are published as they are submitted and meet publication criteria. A unique, consistent, permanent citation identifier (CID) number is assigned to each article at the time of the first publication. Utilization of CIDs allows articles to be fully citable as soon they are published online, and connects the same identifier to all online, print, and electronic versions of the publication. SPIE uses a six-digit CID article numbering system in which:

- The first four digits correspond to the SPIE volume number.

- The last two digits indicate publication order within the volume using a Base 36 numbering system employing both numerals and letters. These two-number sets start with 00, 01, 02, 03, 04, 05, $06,07,08,09,0 A, 0 B \ldots .0 Z$, followed by $10-1 Z, 20-2 Z$, etc.

The CID number appears on each page of the manuscript. The complete citation is used on the first page, and an abbreviated version on subsequent pages. Numbers in the index correspond to the last two digits of the six-digit CID number. 


\section{Contents}

vii Conference Committee

\section{SESSION 1 THEORY}

666302 Microlens laser beam homogenizer: from theory to application (Invited Paper) [6663-01] M. Zimmermann, Bayerisches Laserzentrum GmbH (Germany); N. Lindlein, Institute of Optics, Information and Photonics, Univ. of Erlangen (Germany); R. Voelkel, K. J. Weible, SUSS MicroOptics SA (Switzerland)

666303 Impact of phase errors at the conjugate step on the propagation of intensity and phase shaped laser beams [6663-02]

I. A. Litvin, CSIR National Laser Ctr. (South Africa) and Univ. of Stellenbosch (South Africa);

A. Forbes, CSIR National Laser Ctr. (South Africa) and Univ. of Kwazulu-Natal (South Africa)

666304 Caustic surfaces in a Keplerian two-lens beam shaper [6663-03]

J. A. Hoffnagle, IBM Almaden Research Ctr. (USA); D. L. Shealy, Univ. of Alabama, Birmingham (USA)

666305 A model of the transverse modes of stable and unstable porro-prism resonators using symmetry considerations [6663-04]

L. Burger, A. Forbes, CSIR National Laser Ctr. (South Africa) and Univ. of Kwazulu-Natal (South Africa)

666306 Unwound vortex beam shaping [6663-05]

C. López-Mariscal, J. C. Gutiérrez-Vega, Tecnológico de Monterrey (Mexico)

666307 Propagation dynamics of helical Hermite-Gaussian beams [6663-06]

C. López-Mariscal, J. C. Gutiérrez-Vega, Tecnológico de Monterrey (Mexico)

\section{SESSION 2 DESIGN}

666308 Beam shaping on the base of micro lenslet arrays with the help of diffraction and interference effects [6663-07]

Yu. Miklyaev, D. Hauschild, A. Mikhailov, V. Lissotschenko, LIMO Lissotschenko Mikrooptik GmbH (Germany)

666309 Fly's eye condenser based on chirped microlens arrays [6663-08]

F. C. Wippermann, U.-D. Zeitner, P. Dannberg, A. Bräuer, Fraunhofer Institute for Applied Optics and Precision Engineering (Germany); S. Sinzinger, Technical Univ. of IImenau (Germany)

$66630 \mathrm{~A}$ Laser profile uniformity at the image plane: comparing hard and digital apertures illuminated by a diffractive optical beam shaper [6663-09]

T. E. Lizotte, Hitachi Via Mechanics USA, Inc. (USA) 
6663 OC Designing beam shaping systems basing on spherical catalog lenses [6663-11]

H. Schimmel, LightTrans GmbH (Germany); F. Wyrowski, Friedrich Schiller Univ. (Germany)

\section{SESSION 3 FABRICATION AND TECHNIQUES I}

6663 OD Refractive beam shaping: from Maxwell's Equations to products and applications in laser materials processing (Invited Paper) [6663-13]

O. Homburg, D. Hauschild, P. Harten, L. Aschke, V. Lissotschenko, LIMO Lissotschenko Mikrooptik GmbH (Germany)

$6663 \mathrm{OE} \quad$ Vacuum isostatic micro molding of diffractive structures into PTFE materials [6663-14]

T. E. Lizotte, O. Ohar, Hitachi Via Mechanics USA, Inc. (USA)

6663 OF Methods of designing and fabricating: an equilateral triangle beam splitter [6663-15] J. G. Smith, A. Stockham, MEMS Optical, Inc. (USA)

\section{SESSION 4 FABRICATION AND TECHNIQUES II}

6663 OG High power holographic masks for beam shaping [6663-17]

W. Parker, Creative MicroSystems Corp. (USA)

$6663 \mathrm{OH}$ Characterisation of a spinning pipe gas lens using a Shack-Hartmann wavefront sensor [6663-18]

C. Mafusire, A. Forbes, CSIR National Laser Ctr. (South Africa) and Univ. of Kwazulu-Natal (South Africa); G. Snedden, CSIR Defence Peace Safety and Security (South Africa); M. M. Michaelis, Univ. of Kwazulu-Natal (South Africa)

6663 Ol New approaches for manufacturing refractive beam shapers [6663-19]

S. Kiontke, asphericon GmbH (Germany)

\section{SESSION $5 \quad$ APPLICATIONS}

6663 0J Innovative optical technique speeds up LED wafer scribing production (Invited Paper) [6663-20]

L. Chen, R. Y. L. Hsu, R. J. Z. Lee, Uni-Via Technology Inc. (Taiwan); T. Lizotte, Hitachi Via Mechanics USA, Inc. (USA)

6663 OK Beam shaping for cosmetic hair removal [6663-21]

T. E. Lizotte, T. Tuttle, Hitachi Via Mechanics USA, Inc. (USA)

$6663 \mathrm{OL}$ Wafer dicing utilizing unique beam shapes [6663-22]

T. Lizotte, O. Ohar, Hitachi Via Mechanics USA, Inc. (USA)

6663 OM Advances in MEMS deformable mirror technology for laser beam shaping [6663-23] S. Menn, S. A. Cornelissen, P. A. Bierden, Boston Micromachines Corp. (USA)

$66630 \mathrm{~N}$ Increased efficiency and performance in laser pump chambers through use of diffuse highly reflective materials [6663-24]

B. Waldwick, C. Chase, B. Y. Chang, Labsphere, Inc. (USA) 
666300 The main peculiarities of arranging the optical scheme of acousto-optical spectrometer for the Mexican Large Millimeter Telescope [6663-25]

A. S. Shcherbakov, S. E. Balderas Mata, E. Tepichin Rodriguez, A. Luna Castellanos,

D. Sanchez Lucero, National Institute for Astrophysics, Optics and Electronics (Mexico);

J. Maximov, Molecular Technology GmbH (Germany)

$66630 Q \quad$ A design of optical resonator for donut mode generation [6663-27]

S.-C. Chu, National Cheng Kung Univ. (Taiwan)

\section{POSTER SESSION}

6663 OR Laser beam shaping limitations for laboratory simulation of turbulence using a phase-only spatial light modulator [6663-28]

I. A. Litvin, CSIR National Laser Ctr. (South Africa) and Univ. of Stellenbosch (South Africa);

L. Burger, M. P. De Gama, A. Mathye, A. Forbes, CSIR National Laser Ctr. (South Africa) and Univ. of Kwazulu-Natal (South Africa)

6663 OS Propagation of Helmholtz-Gauss beams in turbulent media [6663-31]

R. J. Noriega-Manez, J. C. Gutierrez-Vega, Tecnologico de Monterrey (Mexico)

6663 OT Characterization of higher-order Mathieu X-waves in the optical domain [6663-32]

J. Davila, J. C. Gutierréz-Vega, Tecnológico de Monterrey (Mexico)

Author Index 
Downloaded From: https://www.spiedigitallibrary.org/conference-proceedings-of-spie on 26 Apr 2023

Terms of Use: https://www.spiedigitallibrary.org/terms-of-use 


\title{
Conference Committee
}

\author{
Symposium Chair
}

Zakya H. Kafafi, Naval Research Laboratory (USA)

Conference Chairs

Fred M. Dickey, Sandia National Laboratories (USA)

David L. Shealy, The University of Alabama, Birmingham (USA)

Program Committee

Daniel M. Brown, Optosensors Technology, Inc. (USA)

Michael R. Duparré, Friedrich-Schiller-Universität Jena (Germany)

Andrew Forbes, Council for Scientific and Industrial Research

(South Africa) and University of Kwazulu-Natal (South Africa)

Julio C. Gutierrez-Vega, Instituto Tecnológico y de Estudios Superiores de Monterrey (Mexico)

John A. Hoffnagle, IBM Almaden Research Center (USA)

Kurt J. Kanzler, Diffractive Laser Solutions (USA)

R. John Koshel, Lambda Research Corporation (USA)

Alexis V. Kudryashov, Moscow State Open University (Russia)

Andrew F. Kurtz, Eastman Kodak Company (USA)

Zsolt J. Laczik, University of Oxford (United Kingdom)

William P. Latham, Air Force Research Laboratory (USA)

Todd E. Lizotte, Hitachi Via Mechanics USA, Inc. (USA)

Günter Luepke, The College of William \& Mary (USA)

Olivier Magnin, C2 Diagnostics (France)

Paul F. Michaloski, Corning Tropel Corporation (USA)

Thomas D. Milster, The University of Arizona (USA)

Tasso R. M. Sales, RPC Photonics, Inc. (USA)

José M. Sasian, The University of Arizona (USA)

Kenneth J. Weible, SUSS MicroOptics SA (Switzerland)

Uwe-Detlef Zeitner, Fraunhofer-Institut für Angewandte Optik und Feinmechanik (Germany)

Shuyan Zhang, The College of William \& Mary (USA)

Session Chairs

1 Theory

John A. Hoffnagle, IBM Almaden Research Center (USA) 
Design

Andrew Forbes, Council for Scientific and Industrial Research

(South Africa) and University of Kwazulu-Natal (South Africa)

3 Fabrication and Techniques I

Todd E. Lizotte, Hitachi Via Mechanics USA, Inc. (USA)

$4 \quad$ Fabrication and Techniques II

Todd E. Lizotte, Hitachi Via Mechanics USA, Inc. (USA)

5 Applications

David L. Shealy, The University of Alabama, Birmingham (USA) 